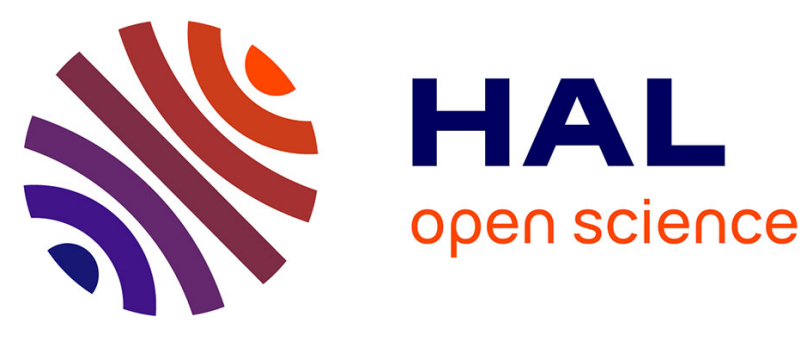

\title{
Myenteric plexitis is a risk factor for endoscopic and clinical postoperative recurrence after ileocolonic resection in Crohn's disease
}

S. Decousus, A-L Boucher, J. Joubert, Marion Goutte, F. Goutorbe, André

Dubois, B. Pereira, P. Dechelotte, Emmanuel Bommelaer, Anthony Buisson

\section{- To cite this version:}

S. Decousus, A-L Boucher, J. Joubert, Marion Goutte, F. Goutorbe, et al.. Myenteric plexitis is a risk factor for endoscopic and clinical postoperative recurrence after ileocolonic resection in Crohn's disease. 11. Congress of ECCO - European Crohn's and Colitis Organisation, European Crohn's and Colitis Organisation (ECCO). INT., Mar 2016, Amsterdam, Netherlands. 1 p., 10.1093/eccojcc/jjw019.044 . hal-01607471

\section{HAL Id: hal-01607471 https://hal.science/hal-01607471}

Submitted on 2 Jun 2020

HAL is a multi-disciplinary open access archive for the deposit and dissemination of scientific research documents, whether they are published or not. The documents may come from teaching and research institutions in France or abroad, or from public or private research centers.
L'archive ouverte pluridisciplinaire HAL, est destinée au dépôt et à la diffusion de documents scientifiques de niveau recherche, publiés ou non, émanant des établissements d'enseignement et de recherche français ou étrangers, des laboratoires publics ou privés. 


\section{DOP015}

\section{Myenteric plexitis is a risk factor for endoscopic and clinical postoperative recurrence after ileocolonic resection in Crohn's disease}

S. Decousus ${ }^{1}$, A.-L. Boucher ${ }^{2}$, J. Joubert ${ }^{1}$, M. Goutte ${ }^{2,3}$, F. Goutorbe ${ }^{2}$, A. Dubois ${ }^{4}$, B. Pereira ${ }^{5}$, P. Dechelotte ${ }^{1}$, G. Bommelaer ${ }^{2,3}$, A. Buisson ${ }^{* 2,3}$ ${ }^{1}$ University Hospital Estaing, Pathology Department, ClermontFerrand, France, ${ }^{2}$ University Hospital Estaing, Gastroenterology Department, Clermont-Ferrand, France, ${ }^{3}$ UMR 1071 Inserm/ Université d'Auvergne; USC-INRA 2018, Microbes, Intestine, Inflammation and Susceptibility of the host, Clermont-Ferrand, France, ${ }^{4} \mathrm{CHU}$ Estaing, Department of Digestive surgery, ClermontFerrand, France, ${ }^{5}$ GM - Clermont-Ferrand University and Medical Centre, Biostatistics Unit, Clermont-Ferrand, France

Background: As surgical resection is not curative in Crohn's disease $(\mathrm{CD})$, postoperative recurrence (POR) remains a crucial issue. The selection of patients according to available risk factors remains disappointing in clinical practice, highlighting the need for best criteria, such as histologic features. We aimed to investigate whether submucosal and myenteric plexitis increased the risk of endoscopic, clinical, and surgical POR in CD.

Methods: From the pathology department database, we retrospectively retrieved the data of all the patients consecutively operated for $\mathrm{CD}$ in our centre. Inclusion criteria are presented in the study flow chart (Figure 1).

Two pathologists, blinded from clinical data, retrospectively reviewed all specimens to evaluate the presence of plexitis at the proximal resection margin. POR prevalence was determined using

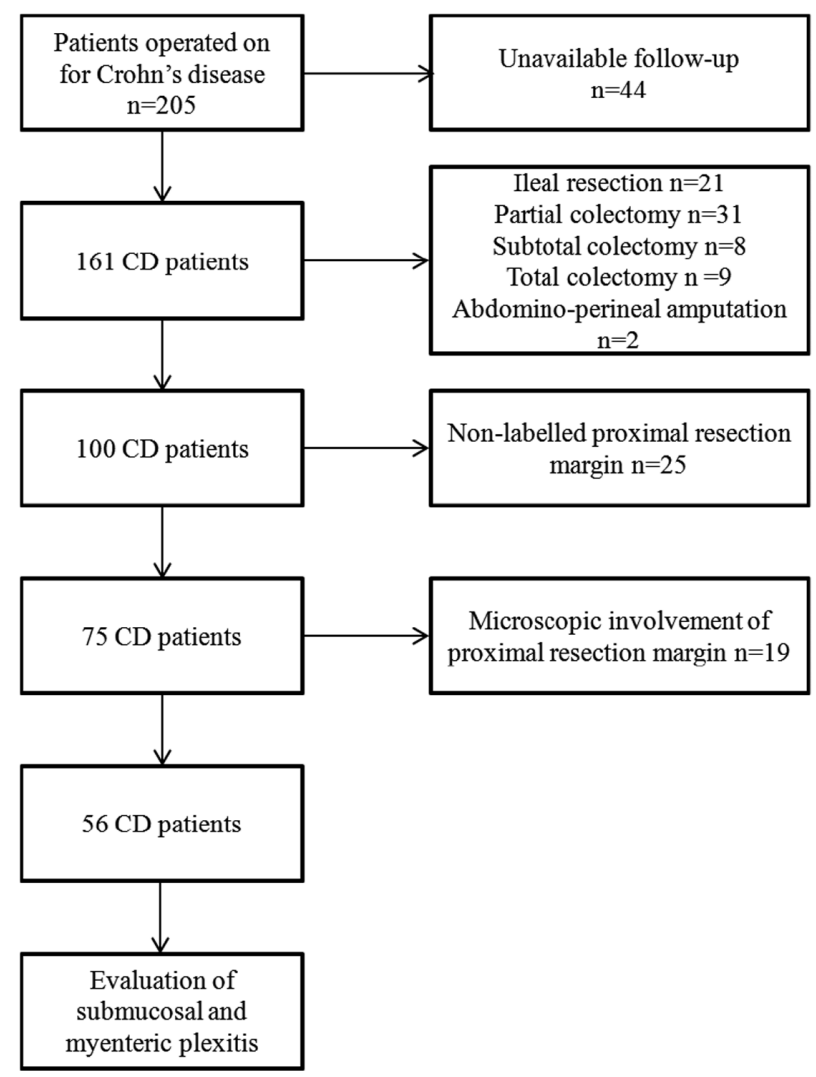

Figure 1. Study flow chart explaining the selection of the included Crohn's disease patients. the Kaplan-Meier method. Cox-proportional hazards regression was used in a multivariate situation by backwards and forwards stepwise analysis of the factors considered significant in univariate analysis (log-rank test) adding systematically the 5 risk factors according to ECCO guidelines: smoking, perianal lesions, previous intestinal resection, fistulising phenotype, and resection length > $50 \mathrm{~cm}$. Results were expressed as hazard ratios (HR) and $95 \%$ confidence intervals (CI 95\%).

Results: Of the 75 included CD patients, 19 (25.3\%) had histological involvement of resection margin, including 9 specimens with presence of granuloma on the proximal resection margin. Inflammatory cells count for myenteric and submucosal plexus were performed in 56 patients. The prevalence of endoscopic, clinical, and surgical POR at 5 years was $69.0 \%, 61.6 \%$, and $17.9 \%$, respectively. In multivariate analysis, the myenteric plexitis was the only risk factor for endoscopic POR (HR 8.83 CI 95\% [1.6-48.6], $p=0.012$ ), and the presence of at least 1 myenteric lymphocyte (HR 4.02 CI 95\% [1.411.2], $p=0.008$ ) or one myenteric neutrophil (HR 23.0 CI $95 \%$ [3.3-160.4], $p=0.002$ ) were predictive of clinical POR. Fistulising phenotype (B3 according to Montreal classification) was associated with increased risk of surgical POR (HR 4.29 CI 95\% [1.0-18.9], $p=0.05$ ). We observed no histologic predictor for surgical POR.

Conclusions: Myenteric plexitis in proximal margins of ileocolonic resection specimens is independently associated with endoscopic and clinical POR in CD. Myenteric plexitis research added to clinical risk factors could be very helpful to stratify patients according to their POR risk and should be encouraged in CD.

\section{DOP016}

Postoperative clinical recurrence is not different in Crohn's disease patients classified as i2 on the Rutgeerts score with lesions confined to the ileocolonic anastomosis than in those with lesions of the neoterminal ileum

P. Bayart*1, N. Duveau ${ }^{1}$, M. Nachury ${ }^{1}$, P. Zerbib ${ }^{1}$, R. Gerard ${ }^{1}$, J. Branche ${ }^{1}$, V. Maunoury ${ }^{1}$, A. Boruchowicz ${ }^{2}$, M. Boualit ${ }^{2}$, J.-E. Laberenne $^{3}$, O. Manolache ${ }^{3}$, G. Pineton de Chambrun ${ }^{4}$, B. Pariente ${ }^{1}$ ${ }^{1} \mathrm{CHRU}$ de Lille, Lille, France, ${ }^{2} \mathrm{CH}$ Valenciennes, Valenciennes, France, ${ }^{3} \mathrm{CH}$ Seclin, Seclin, France, ${ }^{4} \mathrm{CHU}$ Montpellier, Montpellier, France

Background: The Rutgeerts score, that comprises 5 grades of severity (i0-i4), is a suitable endoscopic model to predict clinical recurrence after ileocolonic resection in Crohn's disease (CD). Patients with 2 grade represent a particular population with an intermediate risk of clinical recurrence, and definition of i2 grade is heterogeneous characterised by lesions confined to the ileocolonic anastomosis (i2a) or moderate lesions on the neoterminal ileum (i2b). The aim of the present study was to evaluate the probability of recurrence in i2a and $\mathrm{i} 2 \mathrm{~b}$ patients.

Methods: We performed a multicentre retrospective study, including all CD patients who underwent curative ileocolonic resection and who were classified i2 according to the Rutgeerts score. The primary outcome was to evaluate the probability of clinical recurrence in patients classified $\mathrm{i} 2 \mathrm{a}$ and $\mathrm{i} 2 \mathrm{~b}$. Secondary outcome was to evaluate the rate of global CD recurrence defined by clinical recurrence and/or occurrence of radiological lesions, and/or worsening of endoscopic lesions, and/or optimisation of the medical treatment and/or new intestinal resection for CD.

Results: Included were 50 patients: 23 were classified i2a, and 27 were classified i2b. Demographic and clinical characteristics 